\title{
MÚSICA INDÍGENA BRASILEIRA: FILTRAGENS E APROPRIAÇÕES DO COLONIZADOR E DO MÚSICO OCIDENTAL
}

\author{
JOSÉ D'ASSUNÇÃO BARROS ${ }^{1}$
}

UFRRJ

\begin{abstract}
RESUMO: Este artigo - unindo as perspectivas historiográfica, antropológica e musicológica - busca examinar aspectos fundamentais da música indígena brasileira, particularmente a sua dimensão social e a história de sua apropriação e restrição pela cultura ocidental. Busca-se, sobretudo, refletir sobre a inadequação de abordagens que - até a primeira metade do século $X X$ e em alguns casos persistindo ainda hoje - examinaram a prática musical indígena a partir de critérios de escuta e de anotação exclusivamente calcados nos parâmetros ocidentais. $O$ texto intenta refletir sobre as distorções que podem surgir com o deslocamento de uma determinada produção cultural para fora de seu contexto.
\end{abstract}

PALAVRAS-CHAVE: Música indígena brasileira; interação cultural, alteridade.

ABSTRACT: This article, uniting historiographical, anthropologic and musical perspectives, intends to examine fundamental aspects of Brazilian indigenous music, including the social dimension and the history of assimilation and restrictions imposed by the Western culture. It is intended, above all, to reflect on the inadequacy of approaches which have examined the indigenous practical music based on criteria of listening and annotations exclusively cemented on Western parameters. This text is an attempt to reflect the distortions that can arise from a dislocation of a cultural production outside of its context.

KEYWORDS: Brazilian indigenous music; cultural interaction, alterity.

A sujeição de uma sociedade por outra sempre envolve problemas complexos no âmbito da interação cultural. Nas posições extremas, existem os casos em que a sociedade conquistadora ou invasora, sendo em parte admiradora da cultura da sociedade vencida, assimila avidamente traços culturais daqueles que foram submetidos

\footnotetext{
${ }^{1}$ Doutor em História Social pela Universidade Federal Fluminense (UFF); Professor da Universidade Federal Rural do Rio de Janeiro (UFRRJ) nos Cursos de Mestrado e Graduação em História, onde leciona disciplinas ligadas ao campo da Teoria e Metodologia da História e da História Cultural. Entre publicações mais recentes, registram-se os livros O Campo da História (2004); O Projeto de Pesquisa em História (2005), Cidade e História (2007), A Construção Social da Cor (2009) e Teoria da História (2011), todos publicados pela Editora Vozes. E-mail: jose.assun@globo.com .
}

Espaço Ameríndio, Porto Alegre, v. 5, n. 1, p. 9-31, jan./jun. 2011. 
JOSÉ D’ASSUNÇÃO BARROS - Música indígena brasileira...

belicamente (lembremos o caso da assimilação da cultura grega pelo antigo Império Romano). Mas existem também os casos mais frequentes em que, considerando a si mesma como plenamente superior às populações conquistadas, a sociedade invasora incorpora consciente ou inconscientemente um projeto de aniquilar a cultura dos dominados, de diluí-la na sua própria cultura; ou, ainda, um projeto de deixar que esta cultura sobreviva, mas apenas dentro de determinadas condições e limites extremamente restringidos e sob um determinado controle. Estes enfrentamentos culturais podem se dar sob o signo da hostilidade assumida ou do paternalismo, conforme o caso, bem como sob a forma de outras relações de exploração ou de troca de tipos variados.

O universo cultural das várias sociedades indígenas que habitavam a região sul-americana por ocasião da chegada dos europeus, à altura do início da Idade Moderna, sofreu inúmeras dilapidações e sujeições de um e de outro tipo. Alguns historiadores e antropólogos têm se dedicado precisamente a estudar esta dilapidação cultural - as filtragens e apropriações nela envolvidas, as imposições aculturantes, as diluições das culturas indígenas, a sua inserção em uma realidade de mercado - até mesmo com o intuito de poupar da aniquilação esta realidade cultural riquíssima que é a das sociedades indígenas. Aspectos que incluem a vida cotidiana, a cultura material, a mitologia e outros têm merecido desde a primeira metade do século estudos significativos. Mas - talvez pela especificidade deste campo para cujo estudo são requeridos alguns conhecimentos de musicologia a música dos índios brasileiros nem sempre mereceu a devida atenção dos historiadores e antropólogos, senão a partir das últimas décadas².

Nos dias de hoje, e já desde há pelo menos três décadas, já existem estudos antropológicos que examinam a música das Terras Baixas da América do Sul, sem contar outras regiões do continente americano, nos quais já se afirma um decisivo confronto em relação à perspectiva evolucionista, o mesmo ocorrendo na área mais específica da Etnomusicologia. Fora os já clássicos trabalhos de Anthony Seeger (1977 e 1990), há toda uma nova perspectiva não eurocêntrica que começa a ser aberta desde os anos 1970, notadamente com os trabalhos de Rafael de Menezes Bastos ${ }^{3}$. Seria pertinente citar toda uma cadeia de autores no Brasil e em outros países, tais como Hugh-Jones (1979), Ellen Basso (1985), Viveiros de Castro (1986) Jonathan Hill (1993) e Laura Graham (1995), apenas para pontuar alguns nomes. E já existem mesmo obras basilares para a introdução ao estudo

\footnotetext{
${ }^{2}$ Existem, certamente, magníficas contribuições, como, por exemplo, os estudos de Anthony Seeger, que dedicam uma atenção importante à dimensão musical nas sociedades indígenas (SEEGER, 1990). Antes dele, Charles Seeger já registrava importantes observações em um artigo bastante significativo (SEEGER, 1977).

${ }^{3}$ Este mesmo autor, aliás, é responsável por textos que incluem excelentes balanços da produção etnomusicológica recente sobre o tema (BASTOS, 2004 e 2002), devendo-se lembrar ainda o artigo em conjunto com Acácio Piedade (BASTOS e PIEDADE, 1999).
}

Espaço Ameríndio, Porto Alegre, v. 5, n. 1, p. 9-31, jan./jun. 2011. 
JOSÉ D’ASSUNÇÃO BARROS - Música indígena brasileira...

etnomusicológico da música indígena que recolocam este objeto de estudo a partir de uma perspectiva não evolucionista e não eurocêntrica, tal como o já clássico trabalho de Helza Cameu (1977) sem contar estudos dedicados a universos indígenas mais específicos (AYTAI, 1985) e a já expressiva produção de dissertações de mestrado e teses de doutorado 4 .

Entre os historiadores, nota-se menor riqueza de produção sobre a música indígena, e é de se desejar que a mesma plenitude de estudos sobre o universo indígena contemporâneo, tão bem percorrido pelos antropólogos e etnomusicólogos, possa vir a atrair a atenção de uma historiografia voltada para o estudo da música indígena nos séculos anteriores. Neste artigo procuraremos contribuir, ainda que modestamente, para uma reflexão crítica sobre o tema, procurando diminuir a distância entre a reflexão historiográfica e a reflexão musicológica, no intuito de examinar com maior clareza esta questão crucial para a formação da identidade brasileira, que é o estudo da música indígena. O objetivo inicial será o de examinar os problemas de filtragem que se dão quando o estudioso ocidental esforça-se por perceber a música indígena, particularmente considerando-se que já surgem problemas de filtragem nas próprias fontes de que dispõem os historiadores para o estudo da música indígena de períodos não contemporâneos.

Partiremos da lembrança - que hoje já é certamente lugar comum nos campos da antropologia, da etnomusicologia e da história - de que a leitura de uma cultura por outra sempre traz consigo problemas de filtragem decorrentes do fato de que uma cultura impõe àquele que está nela inserido determinadas maneiras de ver e de olhar para as coisas, de escutar e de ouvir objetos sonoros, de produzir pensamentos em uma direção e não em outra (WAGNER, 2010; BARTH, 1998; CERTEAU, 1982; MERRIAM, 1980).

Um exemplo pode ser evocado antes de adentrarmos a especificidade da percepção de objetos sonoros e de produtos musicais de uma outra cultura. Pensemos, por exemplo, nas direções de visualidade que são impostas aos indivíduos de determinada cultura. A história das artes visuais no ocidente mostra que o homem ocidental aprendeu a ver em perspectiva. Tenho diante de mim um quadro em estilo clássico ou neoclássico, onde estão representados dois homens afastados um do outro. Um deles está mais perto de mim como

\footnotetext{
${ }^{4}$ A produção de dissertações e teses, a partir da década de 1990, é particularmente notável; podemos dar os exemplos dos estudos de Aparecido Silva (1997) sobre os Sulina do Alto Purus, de Acácio Piedade (1997) sobre a música indígena do Alto Rio Negro, de Maria Ignez Mello (1999) sobre os Wauja do Alto Xingu, de Deise Montardo (2002) sobre os Kaiowá e Nhandeva e de Monica Arnt (2010) sobre os MbyaGuarani. De igual maneira, outras regiões da América do Sul e do mundo, que não apenas aquelas inseridas no território brasileiro, tem encontrado um espaço significativo de investigação, tal como nos estudos de Steven Feld (1982) sobre os Kaluli da Nova Guiné e de Dale Olsen (1996) sobre povos indígenas da Venezuela.
}

Espaço Ameríndio, Porto Alegre, v. 5, n. 1, p. 9-31, jan./jun. 2011. 
JOSÉ D’ASSUNÇÃO BARROS - Música indígena brasileira...

observador da cena. É retratado, por isso, em tamanho maior. O outro, mais afastado no espaço em relação a este mesmo ponto de observação, é representado em tamanho menor. Este artifício da perspectiva, que pode ser acrescido de outros recursos como o uso da arquitetura para reforçar esta impressão de afastamento, constitui-se na verdade de um código visual que os indivíduos inseridos na cultura ocidental aprendem desde crianças. Aprende-se a olhar para as coisas em perspectiva. Esta maneira de olhar para uma figura - um desenho, por exemplo - não é algo natural, mas cultural.

Imaginemos agora que se colocou diante do mesmo quadro um indivíduo inserido em outro sistema cultural que não desenvolve nos indivíduos nele incluídos este mesmo processo de leitura das representações visuais. Este novo indivíduo, supondo que não tenha aprendido a ver em perspectiva, estará diante de duas figuras de homens de tamanhos diversificados, que facilmente poderá interpretar como as representações de um gigante e de um anão. O seu olhar não se encaminha culturalmente para examinar a redução no tamanho das figuras como índices de afastamento no espaço. Assim, diante de uma mesma representação visual, dois indivíduos poderão produzir leituras distintas, conforme a tábua de leituras que trazem consigo em decorrência de sua inserção em seu próprio meio cultural.

Com os objetos sonoros ocorre algo similar. Uma cultura já impõe necessariamente àqueles que dela participam uma determinada maneira de ouvir, de produzir e perceber objetos sonoros e de separar o que será considerado som musical e ruído - para já considerar neste último caso o problema da produção artística de sonoridades. Os indivíduos que participam de uma cultura, da mesma forma, atribuirão diferentes significados e funções sociais às suas produções sonoras. A música, por exemplo, terá funções diferentes em sociedades distintas, para além de ser percebida da maneira diferenciada pelos indivíduos pertencentes a estas sociedades distintas. Quando ouvimos música, uma determinada direção mental já nos força a escutar em uma direção auditiva e interpretativa e não em outra, a descartar certos ruídos e classificar outros como sons musicais, a recriar a partir de um determinado padrão de escuta aquilo que estaremos ouvindo (ROSEN, 2000, p.25).

Não esqueceremos o fato, tão bem assinalado pelos pioneiros nos estudos antropológicos de música indígena, que "todo ato de fazer música tem componentes espaciais, temporais, gestuais e interpretativos que também são fundamentalmente não verbais" (SEEGER 1990, p. 84). Uma cultura acostumada a registrar a realidade sonora em pautas musicais, que excluem as referências gestuais, espaciais, ambientais e mesmo interpretativas - como é o caso da prática musical erudita nas sociedades ocidentais -, pode estar deixando de fora, ao se empenhar em transferir para uma pauta musical a realidade musical a ser apreendida, componentes fundamentais da música produzida por

Espaço Ameríndio, Porto Alegre, v. 5, n. 1, p. 9-31, jan./jun. 2011. 
JOSÉ D’ASSUNÇÃO BARROS - Música indígena brasileira...

uma sociedade musicalmente distinta da sua ${ }^{5}$.

Todas estas questões, obviamente, interferem ativamente quando um indivíduo pertencente a uma determinada cultura - um homem ocidental, por exemplo - coloca-se diante dos objetos sonoros ou da música produzida por indivíduos pertencentes a outros meios culturais, como um grupo de indígenas, por exemplo. Voltaremos ainda a estas questões, mas antes retomaremos a questão do encontro histórico entre estes dois meios culturais diferenciados que se produziu a partir do confronto dos portugueses com os povos indígenas que, no século XVI, habitavam esta parte da América do Sul que futuramente viria a constituir o Brasil.

Desde já lembraremos que o indígena brasileiro foi lançado, desde o primeiro momento de contato com o homem branco europeu, em um duplo processo que envolve simultaneamente a 'aculturação' e a 'redução de suas comunidades'. Quando não em momentos de maior aceleração e radicalismo, este processo representa no mínimo um gradual esquecimento da cultura indígena, atingido por dois caminhos complementares. Na "aculturação", o índio é levado a esquecer de si mesmo, a dissolver sua cultura na do homem branco, a silenciar a sua música para escutar um rádio de pilha. No 'desaparecimento das comunidades', é o homem branco quem se esquece dos índios, deixando que suas aldeias sejam atropeladas pela civilização de matriz ocidental, acantonando-os em áreas cada vez mais restritas. Perde. com isto, a oportunidade de conhecer um lado do universo que poderia em muitos aspectos enriquecer a sua experiência humana ${ }^{6}$.

Se quisermos recuar aos primeiros instantes deste complexo processo, poderemos retornar ao tempo dos franciscanos e jesuítas que aqui estiveram no século XVI para catequizar o índio, em nome da Igreja e segundos os interesses da empresa colonizadora. A música foi então utilizada como poderoso instrumento de conversão: levava-se os nativos a participarem de autos religiosos, a cantarem e a dançarem sob a ordem e o controle eclesiástico, a abandonarem os seus instrumentos

\footnotetext{
${ }^{5}$ Anthony Seeger registra o seguinte depoimento: "Sempre que eu cantava, os Suyá denominavam o que eu fazia de ngere. Mas ngere significava tanto uma canção (melodia) como os movimentos que a acompanhavam. Posição e dança são assim uma parte integrante da música, sendo todos parte de um único ato comunicativo chamado ngere" (SEEGER 1990, p. 85).

${ }^{6}$ Os dados de redução das comunidades indígenas são trágicos. Estima-se que, à época da chegada dos portugueses, no século XVI, existiam cinco milhões de nativos nas terras que mais tarde constituiriam o Brasil. Nos tempos recentes, este número oscilou entre cento e cinquenta mil, à época do levantamento promovido por Darcy Ribeiro, e setecentos mil indivíduos, em artigos e fontes que já se referem às décadas mais recentes (RIBEIRO, 2004, p. 330; SOHN, 2009, p. 8; MELLATI, 2004, p. 7). Para maiores detalhamentos demográficos da população indígena, inclusive especificando as diversas regiões, ver Mellati (2004) e também Ricardo (2000).
}

Espaço Ameríndio, Porto Alegre, v. 5, n. 1, p. 9-31, jan./jun. 2011. 
JOSÉ D’ASSUNÇÃO BARROS - Música indígena brasileira...

- as suas taquaras, tore e teiru - em favor das flautas, gaitas e violas europeias.

Da mesma forma, aquilo que de um ponto de vista pretensamente "civilizado" era percebido com inquietação no canto dos índios - com suas notas rodeadas de efeitos de afastamento em relação aos sons fixos que os europeus considerariam afinados - era "limpado" para se adequar à afinação europeia. Os improvisos eram banidos em favor do som da pauta, do som controlado rigorosamente pelo "mestre de capela". A irregular "multiplicação de cantos", que em alguns casos tendia a produzir uma simultaneidade de repetições minimamente defasadas do mesmo desenho melódico, cedia lugar ao mais rigoroso uníssono herdado da disciplinada prática monástica do canto gregoriano. A partir de uma infinidade de operações e repressões, enfim, a música renascentista e o cantochão invadiam a paisagem sonora dos indígenas (Cf. PREISS, 1988; SEPP, 1980).

É verdade que sempre existiram os "civilizados" curiosos, e às vezes conscientes, que se mostraram empenhados em compreender a cultura indígena nas suas próprias bases e em registrar os seus mitos, os seus costumes, a sua música. O século XIX, por exemplo, trouxe um número significativo de pesquisadores e viajantes europeus que estavam precisamente interessados em conhecer um Brasil que Ihes era percebido como "exótico" - e esteve na moda a formação de missões culturais, de expedições e de viagens isoladas que geraram uma rica literatura interessada em divulgar na Europa aspectos relacionados à natureza tropical, ao encontro de raças que se dava na sociedade colonial, e ao índio em particular (BELLUZZO, 1994, p. 18-63).

Os pesquisadores austríacos Spix e Martius (1938), por exemplo, foram dois destes incansáveis viajantes oitocentistas que se engajaram na missão de registrar a vida e as especificidades da natureza e da cultura do Brasil Colonial. Aqui chegaram em 1817, conjuntamente com outros pesquisadores e artistas europeus dispostos a decifrar e retratar este "novo mundo" de imensos espaços abertos, preenchidos por uma fauna e flora exuberantes e habitados por uma sociedade bem diferente da sua - tanto no que se refere à sociedade colonial das cidades brasileiras, engenhos de açúcar e fazendas de café, como no que se refere aos "povos das florestas" que tantos os impressionaram7.

Além de sua célebre obra Viagem pelo Brasil, Spix e Martius ocuparam-se em coletar melodias folclóricas e indígenas, que deixaram registradas em uma obra que até hoje serve de referência aos musicólogos interessados em estudar a cultura musical indígena (SPIX e MARTIUS, 1938). Assim, podemos hoje contar com o conhecimento de diversos elementos melódicos oriundos de comunidades indígenas que

\footnotetext{
${ }^{7}$ Foi esta mesma expedição austríaca que trouxe o pintor Thomas Ender (1795-1875), responsável por inúmeras aquarelas que tematizaram paisagens naturais e urbanas do Rio de Janeiro e arredores. Sobre Thomas Ender, ver Ribeiro (2007).
}

Espaço Ameríndio, Porto Alegre, v. 5, n. 1, p. 9-31, jan./jun. 2011. 
JOSÉ D’ASSUNÇÃO BARROS - Música indígena brasileira...

já até desapareceram. É o caso, por exemplo, da seguinte sequência recolhida pelos dois pesquisadores austríacos:

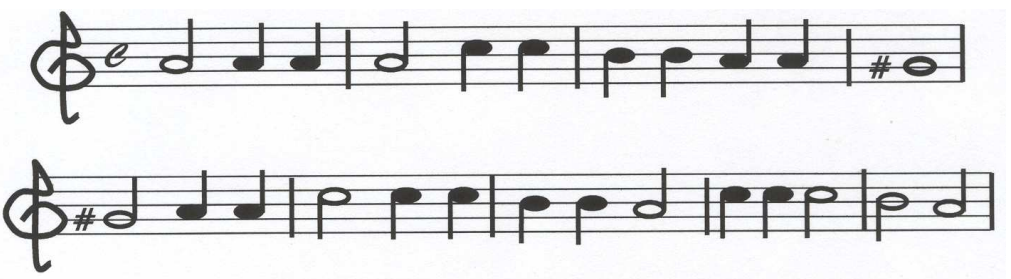

Dança dos Juris-Tabocas - Spix e Martius, n. 8 (SPIX e MARTIUS, 1938, p. 347).

Mais tarde, no contexto histórico do século XX e do Brasil Republicano, outras investidas no sentido de recolher dados da cultura e da música indígena prosseguiram. A Missão Rondon, por exemplo - que não tinha propósitos meramente culturais, mas principalmente o de assegurar um maior conhecimento e controle do espaço nacional -, elaborou também a sua recolha de melodias indígenas. Os fonogramas trazidos por esta Missão encontram-se hoje no Museu Nacional, e foram feitos registros em partituras, publicados em seguida (LACED, 2008)8.

Tanto as melodias recolhidas no século XIX como as recolhidas no século $X X$ enriqueceram sensivelmente as possibilidades de um maior conhecimento da música indígena. Mas não há como negar que estes empreendimentos arrastam atrás de si uma certa gama de problemas a serem enfrentados. Os homens que colheram e anotaram exemplos musicais indígenas eram, via de regra, portadores de uma posição radicalmente externa à realidade que pretendiam investigar, e em todos os casos eram ouvintes ou estudiosos extremamente familiarizados com a música ocidental, cujos pressupostos eram etnocêntricos e evolucionistas.

Os viajantes europeus do século XIX e os rondonistas do século $\mathrm{XX}$ estavam rigorosamente se defrontando com uma realidade cultural nova e, sobretudo, com uma música que ainda não tinham ouvido. Por mais bem intencionados que sejam estes registros sobre a música indígena, há algo que se perde desta música ao ser filtrado pelo padrão de escuta ocidental ou pelos seus parâmetros estéticos.

Assim, alguns dos estudiosos que tiveram a oportunidade de coletar melodias e informações sobre a música indígena tenderam a proceder a uma leitura desta música de acordo com os parâmetros musicais europeus, por vezes descaracterizando-a nas suas anotações. Pode-se dizer que a própria acomodação gráfica do som nativo a uma pauta de cinco linhas, a uma armadura de clave indicativa de tonalidade,

\footnotetext{
${ }^{8}$ Estes registros foram elaborados por Astolfo Tavares a partir dos fonogramas trazidos pela Missão Rondon, e podem ser examinados na famosa obra Rondônia, elaborada por E. Roquete Pinto pouco depois da coleta empreendida pela Missão Rondon (ROQUETE PINTO, 1935). Os arquivos sonoros também estão disponíveis em LACED (2008).
}

Espaço Ameríndio, Porto Alegre, v. 5, n. 1, p. 9-31, jan./jun. 2011. 
a um compasso gerador de uma métrica regular, constitui por si mesma uma interferência no material coletado.

A Dança dos Juris Tabocas, citada, passa a ser examinada como um trecho musical em "lá menor" - embora as quatro notas que a constituem (sol \# - lá - si - dó) não autorizem exclusivamente esta interpretação ${ }^{9}$. A sua rítmica passa a ser traduzida em termos de um compasso quaternário com regularidade métrica, de acordo com os padrões de acentuação habituais na música de tradição européia, e assim por diante10. Involuntariamente, o pesquisador de tradição ocidental projeta um parâmetro de análise tonal em uma cultura musical que desconhece a tonalidade, e impõe uma rítmica específica a uma prática musical que pode trazer no seu íntimo outras soluções que não as nossas para a organização do espaço sonoro.

\section{O obstáculo dos padrões de escuta}

As hesitações dos musicólogos, compositores e historiadores da música da primeira metade do século $X X$, que se empenharam pela primeira vez em assimilar, registrar e analisar mais sistematicamente a prática musical indígena, são índices de uma questão bastante complexa que envolve a apreensão de quaisquer objetos (e sujeitos) sonoros, quanto mais de objetos sonoros em situação de estranhamento cultural. Para além da "escrita" - gesto de transferir de forma simplificada para os símbolos visuais a complexidade de um fenômeno essencialmente sonoro -, a "escuta", já se sabe, é inevitavelmente um ato recriador. Charles Rosen tece alguns comentários bastante relevantes a respeito:

Sempre que ouvimos uma música, colocamos nossa imaginação acústica para trabalhar. Nós a purificamos, dela subtraindo aquilo que é irrelevante com relação à massa indigesta de sons que atingem nossos ouvidos as cadeiras que rangem nas salas de concertos, as tosses ocasionais, o barulho do trânsito lá fora; instintivamente corrigimos a afinação, substituímos as notas erradas pelas corretas, e apagamos da nossa percepção musical o som arranhado do arco do violino; em poucos minutos conseguimos filtrar a ressonância

\footnotetext{
9 "Mais curioso ainda, porém, é surpreender, em certas melodias, indiscutível senso de tonalidade, reconhecendo funções atrativas a determinados sons e delineando os acordes básicos da tônica e da dominante". Estas são palavras de Luís Heitor Azevedo, que exemplifica a seguir com a mesma melodia de Spix e Martius que aqui tomamos para exemplo (AZEVEDO, 1938, p. 29).

${ }^{10}$ Mais raros são posicionamentos como o de Luciano Gallet. Ao escutar os fonogramas do Museu Nacional trazidos pela Missão Rondon, o compositor e pesquisador admite que, apesar do registro que tentaram lhe impor, a música indígena apresenta uma "quadratura rítmica sem relação alguma com a nossa" (GALLET, 1934, p. 44).
}

Espaço Ameríndio, Porto Alegre, v. 5, n. 1, p. 9-31, jan./jun. 2011. 
JOSÉ D’ASSUNÇÃO BARROS - Música indígena brasileira...

excessiva da catedral que interfere na clareza da condução de vozes. Ouvir música, assim como, entender a linguagem, não constitui um ato passivo, mas um ato cotidiano, tão comum, da imaginação criadora, que seu mecanismo é aceito sem reservas. Separamos a música do som (ROSEN, 2000, p. 25).

Quando nos empenhamos em escutar uma música pertencente a uma tradição cultural com a qual não estamos acostumados, a interferência do imaginário sonoro pode se tornar, ao invés de corretora e complementadora, literalmente deformadora. Esta ou aquela sonoridade que um certo padrão cultural de escuta julga não fazer parte do som musical puro, mas sim do âmbito dos ruídos a serem relegados ao esquecimento auditivo, pode ser extremamente importante em um outro padrão cultural de escuta. O que o homem branco ocidental chama de ruído, o indígena pode sentir como som; o portamento em quarto de tom que o europeu descarta como "erro de afinação", o nativo brasileiro pode considerar como parte integrante e fundamental do seu som musical; os ruídos da floresta, que parecem ao europeu intrometerem-se indevidamente no espetáculo sonoro, podem ser para o índio os principais convidados. Como separar a música do som na passagem de uma cultura musical a outra, se cada cultura redefine por sua conta o que é o ruído e o que é o som?

Este é o problema central a ser enfrentado na captação da música indígena. Rigorosamente, os materiais nativos recolhidos em períodos anteriores pelos pesquisadores estrangeiros e brasileiros - que hoje são fontes para o trabalho dos mais dedicados musicólogos - precisariam ser submetidos a uma análise crítica, sob o risco de que se tome por música indígena a leitura que o olhar e os ouvidos ocidentais produziram sobre esta música em uma época em que ainda não havia a possibilidade de contar com uma tecnologia mais apurada, capaz de assegurar mais registros audiovisuais e sonoros das práticas musicoperformáticas indígenas. Mas, para os períodos históricos anteriores, é com estes materiais que contamos, e é preciso trabalhar sobre eles.

Uma contribuição importante foi a do compositor e musicólogo Luciano Gallet nos seus Estudos de Folclore (GALLET, 1934, p. 44), que adotou uma postura crítica ao examinar a notação musical com que os viajantes e etnógrafos registraram exemplos colhidos da tradição indígena. Questiona, por exemplo, os registros gráficos em partitura elaborados a partir de gravações colhidas pela Missão Rondon. Ao examinar diretamente os fonogramas do Museu Nacional, Luciano Gallet atestou ter escutado intervalos diferentes dos nossos, incluindo talvez os quartos de tom, enquanto nas transcrições correspondentes ocorre, via de regra, uma adaptação falseada para o modelo heptatônico e temperado ocidental.

Sobretudo, Gallet (1934) chama a atenção para a presença, não

Espaço Ameríndio, Porto Alegre, v. 5, n. 1, p. 9-31, jan./jun. 2011. 
JOSÉ D’ASSUNÇÃO BARROS - Música indígena brasileira...

notificada naquelas transcrições (mas perceptível a partir do material fonográfico), de cantos com multiplicação de vozes, identificando-se ali um tipo de polifonia bem distinta da nossa. São talvez expressões polifônicas algo similares às dos povos africanos, fundadas em motivos repetitivos que soam defasados e que produzem uma teia sonora complexa que, para a organização auditiva do homem ocidental mediano, soam, por vezes, como um espaço sonoro caótico e desorganizado. Na transcrição da Missão Rondon, adaptada às noções ocidentais e ao seu padrão de escuta, estas especificidades da música indígena são como que "passadas a limpo" (mas de fato perdidas).

A partir deste e de outros casos, é preciso notar que existe uma dificuldade de alguns estudiosos da música em enxergar certos padrões daquilo que chamam de "música primitiva" não como uma incapacidade, mas como uma riqueza. Assim, as hesitações sonoras em torno de um ponto de afinação são frequentemente percebidas pelo estudioso ocidental como incapacidades de atingir o som afinado (o seu som afinado!), ao invés de serem percebidas como um halo de riquezas timbrísticas que a voz tece em torno de um foco sonoro.

Para os ouvidos ocidentais incapazes de se abrirem a um outro padrão de escuta, o que escapa ao seu paradigma de precisão sonora é deficiência na emissão do som, é invasão de ruído afetando a pureza melódica, é "primitivismo musical". Joseph Yasser já observava que os "primitivos" não são capazes de produzir uma altura definida de som "sem recurso ao portamento incerto de um som indefinido a outro" (YASSER, 1938, p. 98). Custar-lhe-ia admitir que as aproximações ou rodeios imprecisos em torno de uma nota são mais da ordem do efeito que do defeito.

Uma introdução à escuta da música indígena deve principiar por um desmontar de preconceitos auditivos, de modelos monolíticos de percepção do som, de concepções estéticas congeladas e consideradas como únicas, de ilusões de evolucionismo cultural. Não é tarefa fácil, mas deve ser tentada. E vem sendo tentado pelos pesquisadores contemporâneos.

\section{A dimensão social da música indígena}

Antes de mais nada, será preciso compreender que a música indígena é fundamentalmente um fenômeno social, coletivizado tanto na sua produção como na sua escuta. Vale dizer, na música indígena (e nos referimos em particular aos séculos anteriores) todos participam simultaneamente como produtores e fruidores da música, inexistindo as noções de "artista" e de "público", de "palco" e de "platéia", ou tampouco a ideia de "espetáculo". A música indígena integra-se frequentemente a um evento coletivo ou a uma função social importante para toda a comunidade - como uma festa, um canto de trabalho, uma incitação à

Espaço Ameríndio, Porto Alegre, v. 5, n. 1, p. 9-31, jan./jun. 2011. 
JOSÉ D’ASSUNÇÃO BARROS - Música indígena brasileira...

guerra, um ritual de passagem, um encantamento, um exercício de memória coletiva, uma dramatização mitológica.

A experiência solitária do compositor que produz uma música interiorizada, que diz respeito aos seus sentimentos pessoais e às suas percepções subjetivas do mundo, e do ouvinte que consome esta música na sua privacidade - tão típicas da música ocidental de hoje em dia -, inexistia no universo musical nativo de períodos anteriores, embora exista na contemporaneidade, na qual se misturam concepções indígenas de antigas tradições com outras, de novas tradições. Bem ao contrário, a dimensão social da música indígena já se depreende dos primeiros relatos sobre o Brasil, como neste que vem da parte do padre Fernão Cardim, durante uma visitação em 1583, onde o jesuíta surpreende em determinada tribo uma celebração coletiva da guerra (ou talvez uma demonstração simbólica de força):

Não se lhes entende o que cantam, mas disseram-me os padres que cantavam em trova quantas façanhas e mortes tinham feito os seus antepassados. Arremedam pássaros, cobras, e outros animais, tudo trovado por comparações, para se incitarem a pelejar (CARDIM, 1980, p. 152).

Ao mesmo tempo em que ignora o individualismo musical, a musicalidade indígena desconhece este conjunto de fatores que José Miguel Wisnik (1999) chamou de "recalque do ruído", e que se tornou tão típico da música ocidental a partir de certa altura do seu desenvolvimento, só vindo a ser questionado por algumas das novas tendências do século XX. Assim, "a inviolabilidade da partitura escrita, o horror ao erro, o uso exclusivo de instrumentos melódicos afinados, o silêncio exigido à platéia", e mesmo esta "câmara de silêncio onde o ruído estaria idealmente excluído" (WISNIK, 1999, p. 42) - que vem a ser a sala de concerto instituída pela tradição musical burguesa -, nada seria mais estranho ao universo sonoro dos nativos brasileiros.

A música indígena ocorre ao ar livre, ou numa grande oca se for o caso, mas sempre coexistindo com um mundo de ruídos externos que podem vir da própria natureza ou das atividades cotidianas. Chamar estes sons de ruídos, aliás, é já uma projeção de categorias ocidentais que não têm qualquer sentido a partir da ótica indígena, já que o som produzido pelo nativo não se quer isolado ou contrastado em relação ao som produzido pela natureza.

Basta lembrar a passagem acima citada, em que o cronista do século XVI surpreende os indígenas em uma prática musical onomatopeica, com imitação de pássaros e outros animais. Seria dizer que não apenas o indígena integra os seus sons musicais aos sons da floresta, usando-os como ambiente de fundo, como também procura, em algumas oportunidades, ele mesmo produzir os sons típicos da

Espaço Ameríndio, Porto Alegre, v. 5, n. 1, p. 9-31, jan./jun. 2011. 
floresta. Exemplos significativos de integração entre Homem e Natureza.

Foi este mundo sonoro impregnado de práticas coletivas - e de interações diversas com a exuberante natureza que o envolvia - o que mais impressionou os viajantes austríacos Spix e Martius (1938) nas suas estadias entre os povos nativos. Por ora, limitar-nos-emos a transcrever a significativa descrição da Dança dos Puris, registrada pelos dois viajantes na sua obra Viagem pelo Brasil:

Os homens puseram-se em fila; atrás deles puseram-se igualmente em fila as mulheres. Os meninos, aos dois ou três, abraçaram-se aos pais; as meninas agarravam-se por trás, às coxas das mães. Nesta atitude, puseram-se eles a cantar o triste "Han-jo-há, há, há, há, há". Com meneios tristonhos, foram repetidas dança e cantiga, e ambas as fileiras se moveram num compassado andamento a três tempos [... segue-se uma pormenorizada descrição da coreografia ...]

[...] Um negro, que viveu muito tempo entre os Puris, nos interpretou aquelas palavras plangentes, cantadas na dança, dizendo: '- É a queixa de uma flor, que se queria colher de uma árvore, mas que havia caído em terra'. A idéia que nos ocorria, diante deste quadro melancólico, era de saudade de um paraíso perdido. Quanto mais se prolongava a dança dos Puris, tanto mais se excitavam eles, e tanto mais alto elevavam as vozes.

Depois, passaram de uma toada para outra, e a dança tomou feição inteiramente diversa. As mulheres remexiam os quadris fortemente, ora para a frente, ora para trás, e os homens davam umbigadas; [...] Esta dança, cuja pantomina parece significar os instintos sexuais, tem muita semelhança com 0 batuque etiópico, e talvez tenha passado dos negros para os indígenas americanos (SPIX e MARTIUS, 1938, p. 247).

Texto notável, que traz à tona tanto as dimensões imediatamente perceptíveis na música indígena como as traduções culturais involuntariamente encaminhadas pelos próprios observadores europeus. A música é coletiva: homens, mulheres e crianças - todos dela participam. Apenas os observadores europeus, habituados às relações típicas das salas de concerto, as encaram como espetáculo, já que, do ponto de vista dos nativos, todos estão diretamente integrados à música, participando como produtores e fruidores. Também são os espectadores austríacos que traduzem a rítmica indígena em termos de um "andamento compassado a três tempos", da mesma forma que procuram traduzir o mito narrado através de uma analogia com o "Paraíso Perdido" - fantasia literária bem conhecida naquele início de

Espaço Ameríndio, Porto Alegre, v. 5, n. 1, p. 9-31, jan./jun. 2011. 
JOSÉ D’ASSUNÇÃO BARROS - Música indígena brasileira...

século.

Do ponto de vista nativo, a música aqui celebrada em forma de dança é parte integrante da festa, da coreografia que inclui os dois sexos e todas as idades, do exercício de memória coletiva, do mito dramatizado - esta dramatização mítica que sintomaticamente fala por inversão da integração entre homem e natureza (a flor caída em terra é puro desperdício, que não tem lugar no modo de vida indígena).

Também percebemos na sucessão de uma dança mais melancólica a outra - mais rápida e envolvendo movimentos sensuais - a riqueza de sentimentos que podem ser conduzidos pela musicalidade nativa. Por fim, a comparação estabelecida pelos viajantes austríacos entre a Dança dos Puris e o Batuque Etíope é mais um sinal destes tateamentos típicos dos observadores europeus na sua ânsia de compreender o novo através de adaptações com relação ao já conhecido - isto que termina por falsear involuntariamente a realidade cultural indígena no que ela tem de mais específico.

Vale dizer, os viajantes europeus - e outros estudiosos que depois deles vieram - estão sempre em busca de comparar o sistema cultural e musical dos indígenas com o seu próprio, com o oriental, ou com os negros, ao invés de tentar resgatar uma identidade que lhe seja própria.

Deve-se ainda acrescentar que a poderosa dimensão social da música indígena não necessariamente tem de tomar a forma de uma manifestação coletiva. O canto emitido individualmente também tem o seu lugar, mas é preciso compreender que este canto atende sempre a uma função social bem marcada: pode ser o fio condutor de um encantamento utilizado para curar doenças ou evocar a chuva, no benefício de toda a comunidade; ou pode ser a canção que se abre para o registro da memória coletiva ou para a dramatização de um mito, através de cuja reprodução a comunidade inteira procura uma forma de autoconhecimento.

Era em vista das suas potencialidades sociais que o canto individual devia ser preservado, tal como atesta o Padre Fernão Cardim neste curioso texto de 1585 , em que menciona, de passagem, a prática da antropofagia - esse fator tão presente no imaginário de medo e estranhamento que assaltava os exploradores europeus do século XVI:

São muito estimados entre elles os cantores, assim homens como mulheres, em tanto que se tomão um contrário bom cantor e inventor de trovas, por isso the dão a vida e não no comem nem aos filhos (CARDIM, 1980 , p. 243).

Outro depoimento sobre o aproveitamento social do canto emitido individualmente nos chega do século XIX, do livro de Jean Baptiste Debret (1981, p.23) sobre a sua Viagem Pitoresca e Histórica ao Brasil. O pintor-viajante nos deixa entrever que, ao atingir avançada idade e 
JOSÉ D’ASSUNÇÃO BARROS - Música indígena brasileira...

passar a ser "cercado em sua tribo por toda espécie de deferências e sinais de respeito", o índio reconhecidamente experiente passa a incorporar novas funções sociais, sobretudo simbólicas, e que também encontram um veículo apropriado na música:

é ele que se encarrega do discurso aos guerreiros no momento da partida; às vezes chega a acompanhá-los até o campo de batalha para entoar o hino de combate, cujas palavras são tão enérgicas quanto a melodia é monótona, verdadeira salmodia que sobe e desce constantemente através de três ou quatro notas e é executada, ainda por cima, com voz rouca e trêmula (DEBRET, 1981, p. 23).

Conforme se vê, o canto indígena, mesmo quando individual, conserva funções sociais muito bem definidas. Ele é emitido em benefício da comunidade, e é desconhecida tanto a "catarse subjetiva" como o "experimentalismo sonoro" que constrói a música pela música.

\section{Aspectos melódicos da música indígena}

Feitas estas observações primordiais concernentes aos seus aspectos sociais, vejamos em seguida algumas características da música indígena mais referentes à sua constituição intervalar e às alturas melódicas utilizadas. É pertinente lembrar que o parâmetro "altura/melodia" não é de modo nenhum mais importante, na música indígena, que os parâmetros relacionados ao timbre, à performatividade, e à participatoriedade. Os estudiosos que se ocuparam do registro da música indígena brasileira nos períodos anteriores deixaram-nos lacunas em relação a estes aspectos, ao dirigir sua atenção às alturas melódicas. De todo modo, pensamos complementar a discussão sobre a música indígena destes períodos anteriores discutindo os registros em que nos são trazidos os aspectos melódicos.

Deve-se, antes de mais nada, compreender que os povos indígenas não constituem uma realidade cultural única e monolítica, mas sim um grande número de culturas particulares com suas próprias práticas musicais e sistemas de produção sonora ${ }^{11}$. Estas realidades

\footnotetext{
${ }^{11}$ Os índios brasileiros pertencem, na época da chegada dos europeus, a três troncos linguísticos bem diferenciados, cada qual com a sua diversidade de tribos: o Tupi (abarcando as tribos Tupi-Guarani, Manducuru, Juruna, Ariqueme, Tupari), o Macro-Jê (abarcando os Jê, Bororo, Cariri, Coroados, Maxacali, Camacã) e o Aruaque. Havia ainda inúmeras outras tribos que os antropólogos não conseguiram agrupar em nenhum destes grandes troncos - como os Tucano, Caraíba, Xirianá, Maçu, Nhanbiquära, Pano, Mura, Borá, Guaicurus, Catuquina e Txapacura. Este pequeno painel pode dar uma ideia desta vasta diversidade nativa que, desde os tempos da chegada dos portugueses, o colonizador europeu procurou reduzir e aprisionar dentro da palavra "índio" (Cf. GALVÃO, 1960; MELATTI, 1980).
}

Espaço Ameríndio, Porto Alegre, v. 5, n. 1, p. 9-31, jan./jun. 2011. 
particulares podem encontrar uma série de identidades e afinidades no que concernem aos já referidos aspectos sociais da música; contudo, no que concerne às sequências escalares utilizadas pelos vários grupos indígenas, há uma grande gama de variações que devem ser consideradas.

Geralmente podem ser encontrados os sons tendentes à fixação em uma determinada cultura musical através de um exame do seu instrumental. Os grupos indígenas denominados "parecis", por exemplo, possuem três tipos básicos de flautas, que abarcam no seu conjunto os seguintes sons (ROQUETE PINTO, 1935, p. 136):

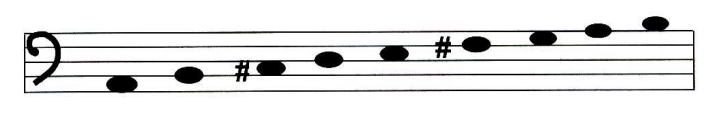

Esta abrangência não significa, por outro lado, que os indígenas parecis utilizem necessariamente uma escala heptatônica, embora esta possibilidade esteja contida no seu aparato instrumental ${ }^{12}$. Na verdade, no conjunto de fonogramas produzidos pela Missão Rondon, e também nas melodias recolhidas por Spix e Martius, transparecem muito mais habitualmente modelos tetracórdicos recortados deste universo maior de possibilidades. É, por exemplo, bastante comum a elaboração de melodias, entre os parecis, a partir da seguinte sequência de notas:

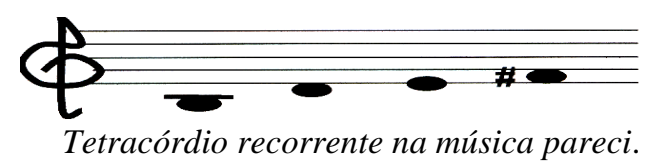

É neste tetracórdio que se baseia a melodia "Teirú", que, aliás, se celebrizou por Villa-Lobos ter nela baseado o primeiro dos seus "Três Poemas Indígenas", para canto e orquestra:

\footnotetext{
${ }^{12}$ A tese de que o modelo escalar heptatônico é o predominante entre os indígenas brasileiros é defendida por Luís Heitor Correa de Azevedo (AZEVEDO 1938, p. 20-23). Mas, na verdade, os próprios exemplos mostrados por este autor revelam que o âmbito de notas extraído das flautas parecis oferece apenas um material primordial para recortes posteriores, já que os exemplos melódicos relativos a este grupo indígena mais se enquadram em modelos pentatônicos defectivos, como o tetracórdio acima exposto.
}

Espaço Ameríndio, Porto Alegre, v. 5, n. 1, p. 9-31, jan./jun. 2011. 


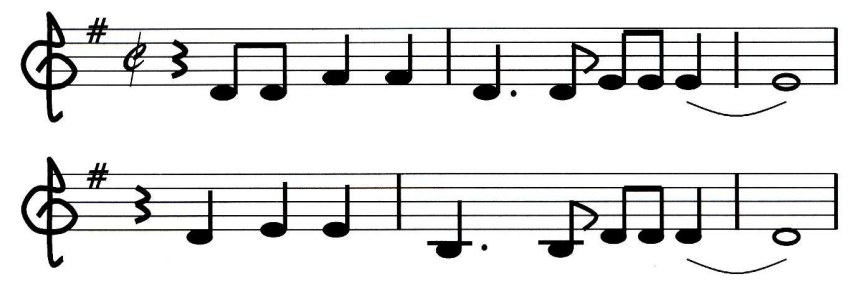

Teirú - Melodia Pareci recolhida pela Missão Rondon.

(ROQUETE PINTO, 1935, p. 328). Fonograma 14.595 do Museu Nacional.

O tetracórdio que dá origem à melodia acima reproduzida (si-rémi-fá\#) foi examinado por analistas e musicistas da primeira metade do século passado como uma escala pentatônica defectiva (ré-mi-fá\#-lasi, na qual está ausente o lá). Obviamente que isto seria tentar adaptar o sistema indígena a outro mais conhecido (o pentatônico oriental), ao invés de considerar o tetracórdio pareci como um material escalar autônomo. Melhor, talvez, é mesmo considerar que a melódica pareci encontra a sua plenitude na possibilidade de criação de sequências musicais sobre quatro notas apenas, formando uma escala tetratônica muito particular. A confirmação de que a melodia acima não é um caso isolado está assegurada por uma série de outras fundamentadas em uma escala de quatro sons do mesmo tipo. É o caso, por exemplo, da melodia pareci "Ualalocê" (ROQUETE PINTO, 1935, p. 324), que corresponde ao fonograma 14.594 do Museu Nacional e que também atraiu a atenção dos nossos compositores eruditos:

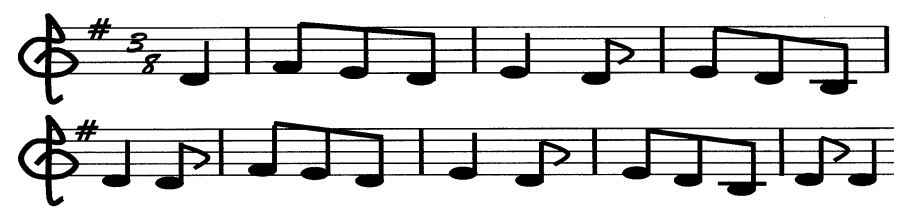

Esta e a melodia anterior já nos colocam diante de um primeiro fator recorrente na música indígena: a utilização de um âmbito sonoro que desenvolve todo o seu potencial criativo em um espaço de alturas que poderia parecer relativamente restrito aos músicos ocidentais. Dificilmente uma música indígena ultrapassa a oitava, e habitualmente restringe-se a âmbitos ainda menores. No caso das melodias atrás transcritas (Teirú e Ulalocê), este âmbito está contido em um espaço de "quinta justa" (si-fá\#).

A aventura melódica vivenciada pela música ocidental - que a partir das extensões mais restritas dos primeiros cantos gregorianos foi enfrentando, no seu desenvolvimento histórico, o desafio de estender cada vez mais o seu âmbito para oitavas mais agudas e mais graves - é desconhecida pela melódica indígena.

Não é nem mesmo seguro considerar que, para algumas tradições

Espaço Ameríndio, Porto Alegre, v. 5, n. 1, p. 9-31, jan./jun. 2011. 
indígenas, tenha algum sentido a ideia de que um som possa ou deva se repetir mais acima para reiniciar uma escala. Desta forma, a questão da "oitava" (termo impróprio em um sistema que não é heptatônico) sequer estaria colocada para os índios. A melódica indígena satisfaz-se, na verdade, em extrair a sua riqueza musical daquilo que por um musicista ocidental poderia ser considerado como umas poucas notas. É possível mesmo encontrar sequências melódicas com duas únicas notas, como neste Grito Ritual dos índios parecis, também recolhido pela Missão Rondon e registrado no fonograma 14.598 do Museu Nacional (ROQUETE PINTO, 1935, p. 328):

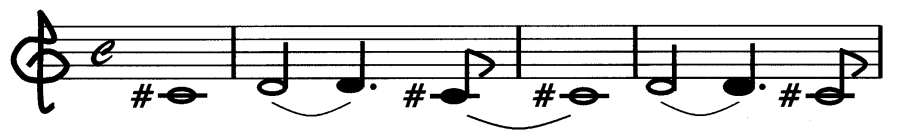

Há o exemplo extremo de algumas das melodias dos índios Bororos, verdadeiros cantos de uma nota só (COLBACCHINI, 1956, p. 114):

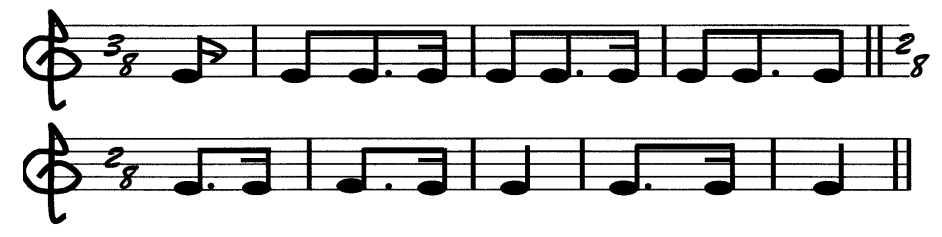

Canto Bororo

E, por outro lado, existem ainda as melodias que se valem de um surpreendente âmbito cromático, embora constituído de poucas notas. É o caso, por exemplo, de melodias construídas a partir de tetracórdios cromáticos como este, que se limita ao âmbito de uma terça menor e que se encontra presente em algumas das melodias recolhidas pela Missão Rondon:

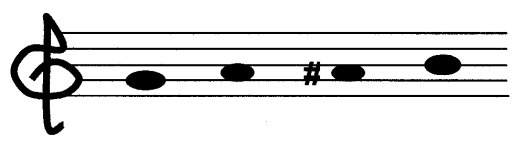

Apenas para citar um último exemplo, é este tetracórdio que está na base da seguinte melodia indígena, correspondente ao fonograma 14.600 do Museu Nacional (ROQUETE PINTO, 1935, p. 330):

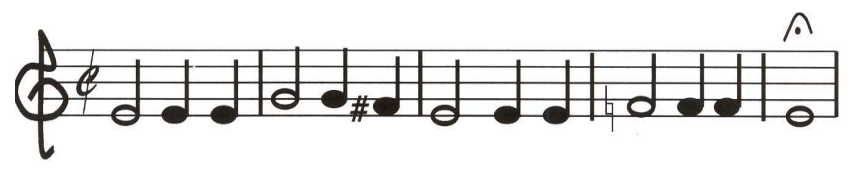

Espaço Ameríndio, Porto Alegre, v. 5, n. 1, p. 9-31, jan./jun. 2011. 
JOSÉ D’ASSUNÇÃO BARROS - Música indígena brasileira...

De uma maneira resumida, procuramos trazer elementos que possibilitem analisar criticamente os registros dos primeiros pesquisadores de música ameríndia, estes que se mostravam exclusivamente preocupados com os contornos melódicos, chamando a atenção do leitor para a existência de outros valores musicais entre os grupos indígenas brasileiros. E, mesmo considerando este parâmetro, que não é o principal para a música indígena, procuramos dar a perceber ainda, com estes exemplos, que a melódica indígena não investe na aventura das amplitudes melódicas, tal como ocorre na música do ocidente europeu ao longo de seu desenvolvimento histórico. Ao contrário, a grande maioria das melodias indígenas extrai sua riqueza de recursos melódicos que, pelos musicistas ocidentais, poderiam ser considerados relativamente simples, embora seja importante lembrar enriquecimentos relevantes como a presença de materiais escalares que, vistos a partir do olhar ocidental, remetem ao uso de cromatismo. Da mesma forma, ocorre em algumas oportunidades a prática da repetição variada de uma mesma melodia, notando-se ainda exemplos de diálogos entre vozes masculinas e femininas que repetem motivos temáticos a alturas diversificadas.

Aqui o historiador-antropólogo e o musicólogo devem se pôr em guarda contra preconceitos carregados de resíduos evolucionistas. Embora os motivos temáticos indígenas utilizem-se amiúde de materiais escalares que poderiam parecer, aos olhares ocidentais, simplificados, não há como pensar que esta música é pobre ou simplória, como chegaram a propor alguns dos musicólogos do início do século (que a viam do ponto de vista de uma produção cultural primitiva). Já mencionamos o fenômeno da "limpeza" de sons que o ocidental é levado a empreender, quando procura transferir um trecho de música indígena para a sua linguagem gráfica e traduzi-lo para o seu sistema de escuta.

Para restituir o universo sonoro dos indígenas à sua riqueza primordial, seria o caso, por exemplo, de recuperar a prática de "cantos multiplicados", através dos quais os índios costumam elaborar uma espécie de simultaneidade polifônica (mas de um outro tipo de polifonia) com sucessivas defasagens de um mesmo trecho melódico. A experiência pode ser feita pedindo-se que quaisquer das melodias que registramos até aqui sejam entoadas por diferentes cantores ou grupos de cantores, mas com defasagens mínimas. O resultado sonoro é uma complexa teia de vozes não coincidentes que entoam, apesar disto, o mesmo motivo. O sucessivo e o simultâneo travam aqui um diálogo não conhecido na prática da música ocidental-européia, e vem daí a dificuldade de esta música ser assimilada pelo ouvido formado no padrão ocidental de escuta.

Por outro lado, deve-se notar que a modalidade do canto ancorado no efeito das vozes multiplicadas não é decorrência de uma incapacidade de cantar rigorosamente em fase, já que o canto em

Espaço Ameríndio, Porto Alegre, v. 5, n. 1, p. 9-31, jan./jun. 2011. 
JOSÉ D’ASSUNÇÃO BARROS - Música indígena brasileira...

uníssono também tem plena manifestação entre os indígenas. Fernão Cardim, autor do primeiro "tratado sobre a terra e as gentes do Brasil", já reconhecia que os índios

têm tal compasso e ordem, que às vezes cem homens bailando e cantando em carreira, enfiados uns atrás dos outros, acabam todos juntamente com uma pancada, como se estivessem todos em um lugar (CARDIM, 1980 , p. 93).

Cantar em uníssono ou multiplicar as vozes é, portanto, uma questão de opção, uma alternativa que tem tudo a ver com o tipo de uso social que se pretende emprestar à música.

Para finalizar e resumir a questão mais ampla da assimilação da música indígena, a partir destes e de outros exemplos, poderíamos reforçar mais uma vez este registro de que os tateamentos aculturantes do homem ocidental, que enfrenta um estranhamento em relação à cultura indígena, são, via de regra, interferidos por uma postura difícil de superar. Da mesma forma que este homem ocidental tendeu, ao menos até meados do século passado, a interpretar os textos e gestos indígenas a partir das suas "tábuas de leitura", é preciso que nos resguardemos da tendência a captar as novas realidades sonoras com que se defronta a partir de suas próprias "tábuas de escuta". Desta forma, o homem ocidental comum tende a avaliar as demais civilizações musicais a partir da sua própria história particular. As escalas utilizadas por outros povos foram frequentemente confrontadas com a sua aventura histórica das amplitudes melódicas e harmônicas (modulações, âmbito escalar abrangendo diversas oitavas, e assim por diante). Os ritmos irregulares e "não medidos" são, nesta operação, desconstruídos na sua essência por uma leitura calcada na aventura do ritmo mensurado, esta que foi acionada a partir do momento em que o músico ocidental abandonou o ritmo lingüístico não medido dos primitivos cantos gregorianos e trovadorescos em benefício da "música mensurada", da pulsação rítmica regular, das barras de compasso instituidoras de uma métrica recorrente a partir do período renascentista. As riquezas vocais timbrísticas e as micro-oscilações são depreciadas em nome da nota precisa, "afinada", limpa de ruídos e de oscilações. A sociabilidade da música é esquecida em nome de uma música individualista que separa produtor e consumidor, que institui a sala de concerto como lugar isolante para uma música que aparta de si o ruído e a própria vida exterior. Eis aqui, em termos muito sintéticos, a "tábua de escuta" do Ocidente.

Destacamos, portanto, a importância da tendência das últimas décadas, a partir de estudos que foram mencionados anteriormente, de examinar a música produzida pelos índios brasileiros levando sempre em consideração, tanto quanto possível, os próprios parâmetros das 
JOSÉ D’ASSUNÇÃO BARROS - Música indígena brasileira...

sociedades nativas examinadas, conforme estes aspectos que foram discutidos no presente artigo: os usos sociais da música e da dança, a ausência de um desejo e de demandas de explorar extensas amplitudes melódicas, a interação entre a música e as sonoridades da natureza, a prática musical indígena como um processo aberto onde a música é recriada no próprio instante de sua execução, a inexistência de uma separação entre o produtor de música e o espectador ou ouvinte. Restituir à música indígena estes parâmetros originais é contribuir para a sua compreensão efetiva. $E$, consequentemente, para a sua preservação em um contexto dinâmico.

\section{Referências bibliográficas}

ARNT, Mônica de Andrade. Processos de criação e registro de expressões musicais entre os Mbyá-Guarani nas Missões. 2010. 138 f. Dissertação (Mestrado em Antropologia Social) - Universidade Federal do Rio Grande do Sul, [2010].

AZEVEDO, Luís Heitor Correa De. Escala, ritmo e melodia na música dos indígenas brasileiros. Rio de Janeiro: Rodrigues e Cia, 1938.

AYTAI, Desidério. O mundo sonoro Xavante. São Paulo: Universidade de São Paulo, 1985. (Coleção Museu Paulista - Etnologia, 5).

BARROS, José D’Assunção. O campo da História. Petrópolis: Editora Vozes, 2004.

O projeto de pesquisa em História. Petrópolis: Editora Vozes, 2005.

Cidade e História. Petrópolis: Editora Vozes, 2007.

A construção social da cor. Petrópolis: Editora Vozes, 2009.

Teoria da História. Petrópolis: Editora Vozes, 2011.

BARTH, Fredrik. Grupos Étnicos e suas Fronteiras. In: POUTIGNAT, Philippe; StreiffSTREIFF-FENART, Jocelyne (Orgs.). Teorias da etnicidade: seguido de grupos étnicos e suas fronteiras de Fredrik Barth. São Paulo: UNESP, 1998. p. 185-228.

BASSO, Ellen B. A musical view of the Universe: kalapalo myth and ritual performances. Philadelphia: University of Pennsylvania Press, 1985.

BASTOS, Rafael José de Menezes. O Índio na música brasileira: recordando quinhentos anos de esquecimento. Antropologia em Primeira Mão, Florianópolis, n. 52, p. 1-12, 2002.

Espaço Ameríndio, Porto Alegre, v. 5, n. 1, p. 9-31, jan./jun. 2011. 
JOSÉ D’ASSUNÇÃO BARROS - Música indígena brasileira...

. Etnomusicologia no Brasil: algumas tendências hoje. Antropologia em

Primeira Mão, Florianópolis, n. 67, p. 4-17, 2004. Disponível em: http://www.antropologia.ufsc.br/67.\%20rafael-bahia.pdf . Acesso em: 26 abr. 2011.

BASTOS, Rafael José de Menezes; PIEDADE, Acácio Tadeu de Camargo. Sopros da Amazônia: sobre as músicas das sociedades TupiGuarani, Mana, Rio de Janeiro, v. 5, n. 2, p. 125-143, 1999.

BELluZZO, Ana Maria de Moraes. Imaginário do Novo Mundo (O Brasil dos Viajantes - 1). São Paulo: Fundação Odebrecht, 1994.

CAMÊU, Helza. Introdução ao estudo da música indígena brasileira. Rio de Janeiro: Conselho Federal de Cultura e Departamento de Assuntos Culturais/MEC, 1977.

CARDIM, Fernão. Tratados da terra e gente do Brasil. Belo Horizonte: Itatiaia, 1980.

CERTEAU, Michel De. A Operação Historiográfica. In: A escrita da História. Rio de Janeiro: Forense Universitária, 1982. p. 65-119.

COLBACCHINI, D. Antônio. I Bororos Prientali “Orarimugudoge" del Matto Grosso (Brasile). Torino: Società Editrize Internazionale, 1956.

DEBRET, Jean Baptiste. Viagem pitoresca e histórica ao Brasil. São Paulo: Círculo do Livro, 1981.

FELD, Steven. Sound and sentiment: birds, weeping, poetics, and song in kaluli expression. Pennsylvania: University of Pennsylvania Press, 1982.

GALLET, Luciano. Estudos de Folclore. Rio de Janeiro: Carlos Wehrs \& Cia, 1934.

GALVÃO, Eduardo. Áreas culturais indígenas do Brasil 1900 - 1959. Boletim Museu Paraense Emílio Goeldi, Antropologia, Belém, n. 8, p. 1-41, 1960.

GRAHAM, Laura. Performing dreams: discourses of immortality among the Xavante of Central Brazil. Austin: University of Texas Press, 1995.

HILL, Jonathan. Keepers of the sacred chants: the poetics of ritual power in an amazonian society. Tucson: University of Arizona Press, 1993.

HUGH-JONES, Stephen. The palm and the pleiades: initiation and cosmology in Northwest Amazonia. Cambridge: Cambridge University Press, 1979.

LACED, Laboratório de Pesquisas em Etnicidade, Cultura e Desenvolvimento. Rondônia 1912: gravações históricas de Roquette-Pinto. Rio de Janeiro: UFRJ/Museu Nacional, 2008. Disponível em: http://ning.it/lyf4Sx . Acesso em: 29 abr. 2011. 
JOSÉ D’ASSUNÇÃO BARROS - Música indígena brasileira...

MANIZER, Henri H. Música e instrumentos de música de algumas tribus do Brasil ..., Revista Brasileira de Música, Rio de Janeiro, v. 1, n. 4, p. 303-327, 1934.

MELATTI, Julio Cezar. Índios do Brasil. São Paulo: Hucitec, 1980.

População indígena. Série Antropológica, Brasília, n. 345, p. 1-39, 2004.

Disponível em: http://ning.it/jJrzlz . Acesso em: 28 abr. 2011.

MELlO, Maria Ignez Cruz. Música e mito entre os Wauja do Alto Xingu. 1999. 214

f. Dissertação (Mestrado em Antropologia Social) - Universidade Federal de Santa Catarina, [1999].

MERRIAM, Alan P. The Anthropology of Music. Evanston: Nortwestern University Press, 1980.

MONTARDO, Deise Lucy Oliveira. Através do Mbaraka: música e xamanismo guarani. 2002. 277 f. Tese (Doutorado em Antropologia Social) - Universidade de São Paulo, [2002].

OLSEN, Dale. A. Music of the Warao of Venezuela: song people of the Rain Forest. Gainesville: University Press of Florida, 1996.

PIEDADE, Acácio Tadeu de Camargo. Música Yepamasa: por uma Antropologia da música no Alto Rio Negro. 1997. 167 f. Dissertação (Mestrado em Antropologia Social) - Universidade Federal de Santa Catarina, [1997].

PREISS, Jorge Hirt. A música nas missões jesuíticas nos séculos XVII e XVIII. Porto Alegre: Martins Livreiro Editor, 1988.

RIBEIRO, Monike Garcia. A Missão Austríaca no Brasil e as aquarelas do pintor Thomas Ender no século XIX. In: 19\&20 - A revista eletrônica de DezenoveVinte, Rio de Janeiro, v. 2, n. 2, n./p., abr. 2007. Disponível em: http://www.dezenovevinte.net/artistas/thomas_ender.htm . Acesso em: 26 abr. 2011.

RIBEIRO, Darcy. Os índios e a civilização: a integração das populações indígenas no Brasil moderno. São Paulo: Companhia das Letras, 2004.

RICARDO, Carlos Alberto (Org.). Povos Indígenas no Brasil - 1996/2000. São Paulo: Instituto Socioambiental, 2000.

ROQUETE PINTO, Edgard. Rondônia. São Paulo: Companhia Editora Nacional, 1935.

ROSEN, Charles. A geração romântica. São Paulo: EDUSP, 2000.

SEEGER, Anthony. Why Suyá sing: a musical anthropology of an amazonian people. Cambridge: Cambridge University Press, 1987. 
O que podemos aprender quando eles cantam: gêneros vocais do Brasil Central.

In: Os índios e nós: estudos sobre sociedades tribais brasileiras. Rio De Janeiro: Campus, 1990. p. 83-106.

SEEGER, Charles. Musicological Juncture 1976. Ethnomusicology, Illinois, n. 21: p. 179-188, 1977.

SEPP, Padre Antonio. Viagem às Missões Jesuíticas e Trabalhos Apostólicos - 16551733. São Paulo: Editora da Universidade de São Paulo, 1980.

SILVA, Domingos Aparecido Bueno da. Música e pessoalidade: por uma Antropologia da Música entre os Kulina do Alto Purús. 1997. 168 f. Dissertação (Mestrado em) Universidade Federal de Santa Catarina, [1997].

SOHN, Maria Cristina D’Almeida Moretz. A distribuição demográfica da população indígena no Brasil: mudanças, conflitos e territorialidade. Rio de Janeiro: ABEP, 2009.

SPIX, Johann Batiste Von; MARTIUS, Carl Friedrich Philipp Von. Viagem pelo Brasil. Rio de Janeiro: Edições Melhoramentos/Imprensa Nacional, 1938. 4 v.

Brasilianische volkslieder und indianische melodien: Musikbeilage zu Reise in Brasilien. München: S. 1, n./d.

STEINEN, Karl von den. Unter den Naturvoelkern Zentral-Brasiliens: Reiseschilderung und Ergebnisse der Zweiten Schingú-Expedition, 1887-1888, Zweite Auflage des Volksausgabe. Berlin: Geographische Verlagsbuchhandlung Dietrich Reimer, 1897.

VIVEIROS DE CASTRO, Eduardo. Araweté: os deuses canibais. Rio de Janeiro: Jorge Zahar, 1986.

WAGNER, Roy. A Invenção da cultura. São Paulo: Cosac Naify, 2010.

WISNIK, José Miguel. O som e o sentido. São Paulo: Companhia das Letras, 1999.

YASSER, Joseph. La tonalité évolutive. La Revue Musicale, Paris, n. 81, p. 98-111, fev. 1938.

Espaço Ameríndio, Porto Alegre, v. 5, n. 1, p. 9-31, jan./jun. 2011. 